\title{
Alkaline serine proteases from Helicoverpa armigera: potential candidates for industrial applications
}

\section{Shaik Mohammad Akbar | Hari Chand Sharma}

Entomology Unit, International Crops Research Institute for the Semi-Arid Tropics (ICRISAT),

Patancheru, Telangana, India

\section{Correspondence}

HC Sharma, Entomology Unit, International Crops Research Institute for the Semi-Arid Tropics (ICRISAT), Patancheru 502324

Telangana, India.

Email:h.sharma@cgiar.org 


\section{1 | INTRODUCTION}

With the recent advances in biotechnology, there has been a growing interest and demand for enzymes with novel properties. Proteases play an important role in metabolism of all forms of life, including prokaryotes, fungi, plants, and animals. Proteases constitute nearly $60 \%$ of the total industrial market for enzymes (Nunes \& Martins, 2001). Proteases are used in various industries such as food, detergent, leather and waste processing, therapeutic, diagnostics, and silver salvaging (Abidi et al., 2008; Kumar \& Takagi, 1999; Zambare et al., 2007). Other applications of alkaline protease include the utilization in peptide synthesis, resolution of the racemic mixture of amino acids, and hydrolysis of gelatin layers of X-ray films (Gupta et al., 2002; Singh et al., 1999).

Investigation on various properties of proteases is a continuous process in enzymology due to both their physiological importance and wide application in research and industries. Due to great industrial demand, there is always a search for alternative sources of proteases with suitable specificity and broad range of stability to various chemicals. Alkaline proteases from bacteria and fungi are the major source for industrial applications (Kumar \& Takagi, 1999; Singh et al., 1999). However, insect proteases have received relatively lesser attention than the microbial proteases. Proteases from insects could be excellent candidates for industrial applications. Proteolysis is an essential part of food digestion in insects mediated by concerted action of several proteases (Anwar \& Saleemuddin, 2002; Sanatan et al., 2013; Visweshwar et al., 2015). Serine protease from insect midguts have been characterized from Osphranteria coerulescens Redtenbacher, Periplaneta americana L., Glyphodes pyloalis Walker, and so on possess important features such as stability under high temperatures, and high activity under alkaline $\mathrm{pH}$ (Mahdavi et al., 2013; Sanatan et al., 2013; Sharifi et al., 2012).

Helicoverpa armigera (Hubner; Noctuidae: Lepidoptera), commonly called cotton bollworm or legume pod borer, is a polyphagous pest, and has been reported to attack more than 180 plant species including pigeonpea, chickpea, cotton, sorghum, groundnut, maize, fruits, vegetables, and forest trees (Sharma, 2005). Lepidopteran larvae consume more food and due to the presence of multiple isozymes of proteases in their midgut they digest and assimilate the ingested food more rapidly and thus grow much faster than mammals and birds, with high metabolic rate. Trypsins, chymotrypsins, cathepsin-B-like proteases, elastases, aminopeptidases, carboxypeptidases, and many serine proteases are dominant proteolytic enzymes in the larval midgut (Chougule et al., 2008; Patankar et al., 2001; Srinivasan et al., 2006; Tabatabaei et al., 2011). The primary digestive proteinases of many insect species are serine proteinases, predominantly trypsin (EC 3.4.21.4) and chymotrypsin (EC 3.4.21.1) (Reeck, et al., 1999; Terra \& Ferreira, 1994). The larval digestive proteinases (trypsin and exopeptidases) were first studied in yellow mealworm, Tenebrio molitor L. (Applebaum et al., 1964). X-ray contact print technique has indicated the presence of 10 isozymes of proteases in the midgut of H. armigera (Parde et al., 2012). H. armigera when reared on a high-protein diet, cDNA library from the midgut showed two genes encoding elastase and 18 trypsin-like and 14 chymotrypsin-like proteinases (Gatehouse et al., 1997).

The digestive enzymes of insects are also of interest for insect control because of their unusual alkaline microenvironment of the midgut (pH 10.0-12.0) (Christeller et al., 1992). Since insect midgut enzymes exhibit highly alkaline pH optima (Anwar \& Saleemuddin, 2002; Parde et al., 2012; Sanatan et al., 2013; Visweshwar et al., 2015), insects can be used as a promising source for isolating proteases that have industrial application. Therefore, in the present study we characterized the serine proteases, trypsin and chymotrypsin, from the midgut of $H$. armigera for their chemostability under extreme alkalinity and temperature conditions that are typically encountered during industrial processing.

\section{I MATERIALS AND METHODS}

\section{1 | Insect culture}

The H. armigera larvae were obtained from the Helicoverpa rearing laboratory, Entomology, International Crops Research Institute for the Semi-Arid Tropics (ICRISAT), Patancheru, Telangana, India. The larvae reared under 
laboratory conditions $\left(27 \pm 1^{\circ} \mathrm{C}, 65 \pm 5 \% \mathrm{RH}\right.$, and 12-h photoperiod) on a chickpea-based diet (Chitti Babu et al., 2014).

\subsection{Isolation of midgut proteases}

Fourth-instar larvae of $\mathrm{H}$. armigera starved for $3 \mathrm{~h}$ were dissected midventrally. About 25 midguts were homogenized in a dounce homogenizer in ice-cold $0.1 \mathrm{M}$ glycine- $\mathrm{NaOH}$ buffer, $\mathrm{pH}$ 10.0. The homogenate was centrifuged at $10,000 \mathrm{rpm}$ for $20 \mathrm{~min}$ at $4^{\circ} \mathrm{C}$, the supernatant stored at $-20^{\circ} \mathrm{C}$ until use. The protein concentration of the midgut extract was estimated by Lowry's method using BSA as a standard (Lowry et al., 1951).

\section{3 | Trypsin and chymotrypsin assay}

Trypsin and chymotrypsin activity in the midgut extract was measured by incubating $10 \mu$ l of gut extract with 1 mM $\mathrm{N} \alpha$-benzoyl-DL-arginine p-nitroanilide (BApNA) and 0.1 mM Suc-Ala-Ala-Pro-Phe-p-nitroanilide (SAAPFpNA) (SigmaAldrich, India) in $0.1 \mathrm{M}$ glycine- $\mathrm{NaOH}$ buffer, $\mathrm{pH}$ 10.0, for 20 and 10 min, respectively, in $1.5 \mathrm{ml}$ Eppendorf tubes at $37^{\circ} \mathrm{C}$. The reaction was terminated by adding $300 \mu \mathrm{l}$ of $30 \%$ acetic acid. The samples were centrifuged and the released pNA was read at $410 \mathrm{~nm}$ by means of spectrophotometer (Hitachi U-2900, Japan) (Purushottam \& Vandana, 2013). One unit of enzyme activity was expressed as the amount of enzyme hydrolyzing $1 \mu$ mole of substrate/min at $37^{\circ} \mathrm{C}$.

\section{4 | Purification}

Fifty milliliters of crude midgut extract ( $750 \mathrm{mg}$ protein) of $\mathrm{H}$. armigera larvae was concentrated using Amicon ultracentrifugal filters. The gut concentrate was applied on hydroxylapatite (HTP) column $(2 \times 10 \mathrm{~cm})$, equilibrated with $0.1 \mathrm{M}$ Tris- $\mathrm{HCl}$ buffer $(\mathrm{pH} 8.0)$. The column was washed with $10 \mathrm{ml}$ of the $0.1 \mathrm{M}$ of Tris- $\mathrm{HCl}$ buffer (pH 8.0). Soon after washing with buffer, proteins were eluted with a stepwise gradient of 0-1.0 M potassium phosphate buffer ( $\mathrm{pH}$ 8.0). The fractions collected in aliquots of $2 \mathrm{ml}$. The trypsin activity eluted at 0.2 to $0.4 \mathrm{M}$ phosphate buffer fractions. Active fractions containing trypsin activity were pooled together, concentrated using Amicon filters, and applied to a column of DEAE sephadex $(2 \times 10 \mathrm{~cm})$ previously equilibrated with phosphate buffer $(0.1 \mathrm{M}), \mathrm{pH}$ 8.0. After washing the DEAE sephadex column with $10 \mathrm{ml}$ of the same buffer, proteins were eluted with a stepwise gradient of $0-1 \mathrm{M} \mathrm{NaCl}$, and $2 \mathrm{ml}$ fractions collected. Trypsin activity eluted at 0.5 and $0.6 \mathrm{M} \mathrm{NaCl}$. Fractions encompassing trypsin activity were combined, and then concentrated using Amicon filters to a final volume of $2 \mathrm{ml}$.

Chymotrypsin was similarly purified as trypsin with certain modifications. After concentrating the midgut crude extract using Amicon ultracentrifugal filters, the concentrate was subjected to HTP column. Fractions of $2 \mathrm{ml}$ each were collected and those having chymotrypsin activity were combined and applied on to the CM sephadex column $(2 \times$ $10 \mathrm{~cm}$ ), previously equilibrated with $0.1 \mathrm{M}$ phosphate buffer $(\mathrm{pH} 8.0)$. The column was washed with $10 \mathrm{ml}$ of the same buffer, the bound proteins were eluted with a stepwise gradient of 0-1 M NaCl, and fractions of $2 \mathrm{ml}$ each were collected. Chymotrypsin activity eluted at 0.6 to $1.0 \mathrm{M} \mathrm{NaCl}$. Fractions containing chymotrypsin activity were pooled, and then concentrated using Amicon filters to a final volume of $4 \mathrm{ml}$. The purified fractions of trypsin and chymotrypsin were dialyzed against $0.1 \mathrm{M}$ glycine- $\mathrm{NaOH}$ buffer ( $\mathrm{pH}$ 10.0), and tested for homogeneity by SDS-PAGE (Laemmli, 1970).

\section{5 | Kinetic studies}

The kinetic parameters, $K_{\mathrm{m}}$ and $V_{\mathrm{max}}$, for the enzyme substrates were determined by measuring the activities of trypsin and chymotrypsin in $0.1 \mathrm{M}$ glycine- $\mathrm{NaOH}$ buffer, $\mathrm{pH}$ 10.0, using L-BApNA and SAAPFpNA, concentration ranging from 
0.25 to $2 \mathrm{mM}$ and 0.02 to $0.2 \mathrm{mM}$, respectively, using Lineweaver-Burk plot (LB plot). LB plot was obtained by linear regression analysis using MS Excel 2010 version.

\subsection{Fluorescent zymogram and molecular mass determination}

Midgut proteases of $H$. armigera were run on $10 \%$ SDS-PAGE. After electrophoresis was performed, the gel was washed in 2.5\% Triton X-100 and in cold distilled water for $10 \mathrm{~min}$ each. The gel was incubated in assay buffer $(50 \mathrm{mM}$ Tris- $\mathrm{HCl}, \mathrm{pH}$ 8.0, containing $10 \mathrm{mM} \mathrm{CaCl}_{2}, 0.005 \%$ Triton X-100 and $50 \mu \mathrm{M}$ Boc-Gln-Ala-Arg-MCA or $50 \mu \mathrm{M}$ SucAla-Ala-Pro-Phe-MCA for detection of trypsin and chymotrypsin, respectively) for $30 \mathrm{~min}$ at $37^{\circ} \mathrm{C}$. The gel was then washed in distilled water and the fluorescent bands of trypsin and chymotrypsin were observed in Gel Documentation System under UV-B transillumination (Bio-Rad Laboratories, Hercules, CA; excitation wavelength for AMC group is $385 \mathrm{~nm}$ ) (Yasothornsrikul \& Hook, 2000). Standard molecular weight markers were loaded in one lane to determine the molecular mass of the purified enzymes. After electrophoresis, the lane was sliced and molecular weight markers were stained using Coomassie Brilliant Blue (R-250). Another lane was loaded with partially purified midgut extract, after electrophoresis the proteases were visualized by incubating the gel in $1.5 \%$ casein in $0.1 \mathrm{M}$ glycine$\mathrm{NaOH}$ buffer, $\mathrm{pH}$ 10, for 60 min; washed; stained with Coomassie Brilliant Blue; and then destained (Visweshwar et al., 2015).

\subsection{Optimum $\mathrm{pH}$ and $\mathrm{pH}$ stability}

Trypsin and chymotrypsin activity in the midgut extract of $\mathrm{H}$. armigera was evaluated by preincubating $10 \mu \mathrm{l}$ of the enzyme in various buffers of $\mathrm{pH}$ ranging from $\mathrm{pH} 4.0$ to 12.0 (acetate buffer $\mathrm{pH}$ 4.0-5.0; phosphate buffer $\mathrm{pH}$ 6.0-7.0; glycine- $\mathrm{NaOH}$ pH 8.0-12.0) for $30 \mathrm{~min}$. at $37^{\circ} \mathrm{C}$ to determine the $\mathrm{pH}$ optima. $\mathrm{pH}$ stability was determined by incubating the purified enzymes in buffers with different $\mathrm{pH}$ range of $7.0-12.0$ for $1 \mathrm{~h}$ at $37^{\circ} \mathrm{C}$. The enzyme activities were assayed as stated above.

\subsection{Effect of temperature and thermal stability}

The activity of purified trypsin and chymotrypsin was evaluated at different temperatures $\left(20-100^{\circ} \mathrm{C}\right)$ by incubating $10 \mu \mathrm{l}$ of the purified enzyme in $1 \mathrm{ml}$ of $0.1 \mathrm{M}$ glycine- $\mathrm{NaOH}$ buffer, $\mathrm{pH} 10.0$, in the presence of respective substrates for $30 \mathrm{~min}$. Stability of the enzymes to temperature was examined by incubating the purified trypsin and chymotrypsin at different temperatures ranging from 50 to $80^{\circ} \mathrm{C}$ for $1 \mathrm{~h}$, and the enzyme activities were determined as described above.

\subsection{Effects of synthetic protease inhibitors and metal ions}

The effect of protease inhibitors on the activity of purified proteases was studied using EDTA (5 mM), EGTA (5 mM), $1 \mathrm{mM}$ each of PMSF, TPCK, TLCK, aprotonin, leupeptin, E64, pepstatin, iodoacetamide, pefabloc, bestatin, antipain, and chymostatin. The inhibitors were preincubated with the purified trypsin and chymotrypsin for $30 \mathrm{~min}$ at $37^{\circ} \mathrm{C}$. Effect of metal ions $\mathrm{Na}^{+}, \mathrm{K}^{+}, \mathrm{Mg}^{2+}, \mathrm{Ca}^{2+}, \mathrm{Fe}^{2+}, \mathrm{Fe}^{3+}, \mathrm{Mn}^{2+}, \mathrm{Zn}^{2+}, \mathrm{Cu}^{2+}, \mathrm{Pb}^{2+} \mathrm{Mo}^{2+}, \mathrm{As}^{3+}$, and $\mathrm{Hg}^{2+}$ on the activities of trypsin and chymotrypsin at $1 \mathrm{mM}$ was also investigated by preincubating the proteases with metal ions for $30 \mathrm{~min}$ at $37^{\circ} \mathrm{C}$, and the proteolytic activities were assessed as stated above. Protease activity without the inhibitor or metal ions was considered as $100 \%$.

\subsection{Effect of surfactants, oxidizing and reducing agents}

The stability of the purified proteases in the presence of surfactants (SDS, CHAPS, TritonX-100, Tween 20, and Tween80) and oxidizing $\left(\mathrm{H}_{2} \mathrm{O}_{2}\right.$ and bleach) and reducing ( $\beta$-mercaptoethanol, DTE, DTT, and urea) agents was determined by 
preincubating them with the purified enzymes for $30 \mathrm{~min}$ at $37^{\circ} \mathrm{C}$. Proteolytic activities were determined as described above and the relative activities determined in relation to the untreated control.

\subsection{Effect of organic solvents}

Effect of various organic solvents such as methanol, ethanol, propanol, butanol, acetone, hexane, DMSO, DMF, benzene, toluene, diethylether, chloroform, benzaldehyde, and formaldehyde on the activity of trypsin and chymotrypsin was examined in a reaction mixture containing $0.1 \mathrm{M}$ glycine- $\mathrm{NaOH}$ buffer $(\mathrm{pH}$ 10.0) and a final concentration of each solvent as $5 \%$. The enzyme activity was determined by incubating the purified trypsin and chymotrypsin with the solvent for 30 min. Enzyme activity was calculated as a percentage in relation to the untreated control.

\subsection{2 | Stability of proteases to commercial detergents}

The stability of purified trypsin and chymotrypsin was assessed in the presence of commonly available commercial detergents such as Ariel, Surf, Tide, Wheel, Vanish, and Rin. Enzyme activities for purified serine proteases was determined by incubating the enzyme with $5 \%$ detergent solution prepared in $0.1 \mathrm{M}$ glycine- $\mathrm{NaOH}$ buffer $\left(\mathrm{pH}\right.$ 10.0) for $30 \mathrm{~min}$ at $37^{\circ} \mathrm{C}$. Commercial detergent solutions were heated prior to assay, at $100^{\circ} \mathrm{C}$ for $30 \mathrm{~min}$ to deactivate the already present proteases in them. Enzyme activity was estimated as a percentage in relation to control.

\subsection{3 | Statistical analysis}

Significant differences between the treatments and treatment means was analyzed by one-way analysis of variance (ANOVA) using F-test and least significant difference (LSD), respectively, in MS Excel 2010 version.

\section{3 | RESULTS}

\section{1 | Purification of trypsin and chymotrypsin}

Trypsin and chymotrypsin was purified up to 13.76- and 14.05-fold, with 11.93 and $13.62 \%$ recovery, respectively (Tables 1 and 2). The specific activity of the serine proteases was 39.37 and $172.56 \mathrm{U} / \mathrm{mg}$ protein, for trypsin and chymotrypsin, respectively. Purity of the proteases was also confirmed by SDS-PAGE.

\section{2 | Kinetic studies}

Trypsin and chymotrypsin showed a hyperbolic dependence on the utilization of their synthetic substrates. $K_{m}$ and $V_{\max }$ were estimated to be $1.25 \mathrm{mM}, 8.2 \mathrm{U}$ and $0.085 \mathrm{mM}, 13.5 \mathrm{U}$, with substrates of trypsin and chymotrypsin, respectively (Fig. 1).

TAB LE 1 Purification of trypsin from midgut of H. armigera

\begin{tabular}{lcccccc} 
& Volume $(\mathrm{ml})$ & $\begin{array}{c}\text { Total Protein } \\
(\mathbf{m g})^{\mathrm{a}}\end{array}$ & Total Activity $(\mathrm{U})^{\mathrm{a}}$ & $\begin{array}{c}\text { Specific Activity } \\
(\mathrm{U} / \mathrm{mg})^{\mathrm{a}}\end{array}$ & $\begin{array}{c}\text { Purification } \\
\text { Fold }\end{array}$ & Yield $(\%)$ \\
\hline Crude extract & 50 & $750 \pm 4.57$ & $2,145.00 \pm 21.58$ & $2.86 \pm 0.05$ & 1.00 & 100.00 \\
\hline Amicon filters & 20 & $680 \pm 5.65$ & $3,225.67 \pm 15.24$ & $4.74 \pm 0.08$ & 1.66 & 150.38 \\
\hline Hydroxyl apatite & 12 & $25 \pm 1.25$ & $488.56 \pm 8.24$ & $19.54 \pm 0.12$ & 6.83 & 22.78 \\
\hline DEAE sephadex & 2 & $6.5 \pm 0.05$ & $255.88 \pm 9.25$ & $39.37 \pm 1.25$ & 13.76 & 11.93 \\
\hline
\end{tabular}

${ }^{a}$ Values in the table represent mean of three replications (mean $\pm S D$ ). 
TAB LE 2 Purification of chymotrypsin from midgut of $H$. armigera

\begin{tabular}{lcccccc} 
& Volume $(\mathrm{ml})$ & $\begin{array}{c}\text { Total Protein } \\
(\mathrm{mg})^{\mathrm{a}}\end{array}$ & $\begin{array}{c}\text { Total Activity }(\mathrm{U})^{\mathrm{a}} \\
\text { Crude extract }\end{array}$ & $\begin{array}{c}\text { Specific Activity } \\
(\mathrm{U} / \mathrm{mg})^{\mathrm{a}}\end{array}$ & $\begin{array}{c}\text { Purification } \\
\text { Fold }\end{array}$ & Yield (\%) \\
\hline Amicon filters & 18 & $825 \pm 10.23$ & $\begin{array}{c}10,135.82 \pm \\
25.24\end{array}$ & $12.29 \pm 0.08$ & 1.00 & 100.00 \\
\hline Hydroxyl apatite & 8 & $56 \pm 8.21$ & $5,752.45 \pm 12.23$ & $102.72 \pm 7.23$ & 8.36 & 56.75 \\
\hline CM sephadex & 4 & $8 \pm 0.05$ & $1,380.5 \pm 10.25$ & $172.56 \pm 8.32$ & 14.05 & 13.62
\end{tabular}

a Values in the table represents mean of three replications (mean $\pm \mathrm{SD}$ ).
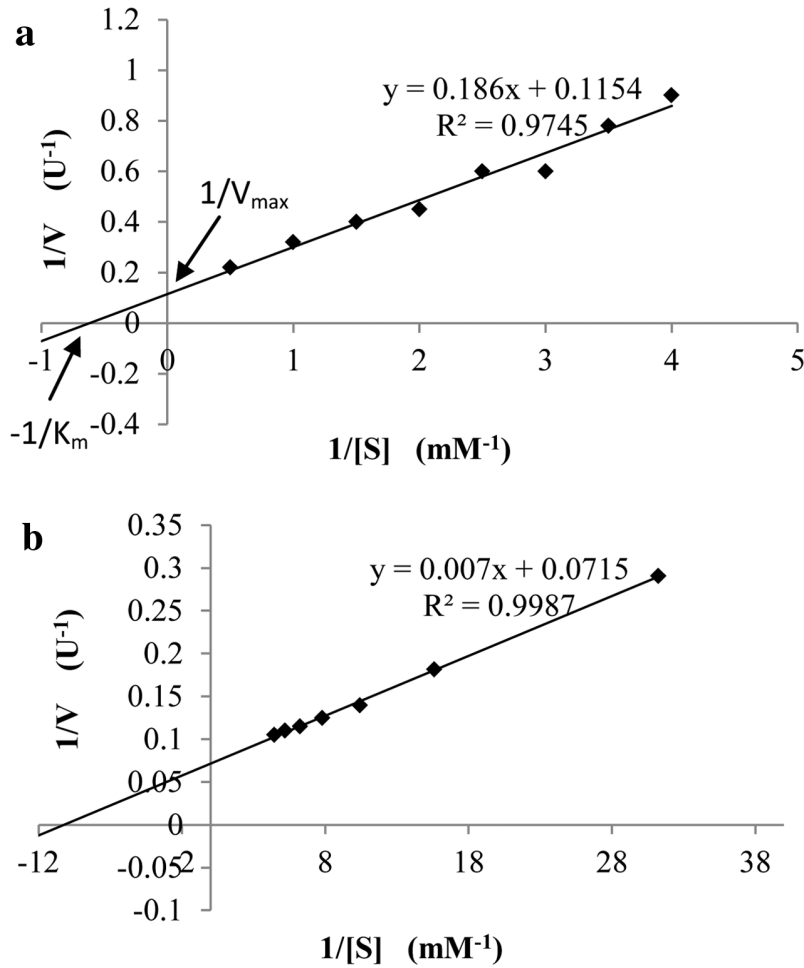

FIGURE 1 Double reciprocal plots for the determination of kinetic parameters of trypsin (a) and chymotrypsin (b) isolated from the midgut $H$. armigera larvae using BApNA and SAAPFpNA as their corresponding substrates

\subsection{Molecular masses of the trypsin and chymotrypsin}

The fractions exhibiting trypsin and chymotrypsin activity were loaded on SDS-PAGE for separation. Trypsin and chymotrypsin were detected by fluorescent zymogram, where the liberated AMC (7-amino-4-methyl-coumarin) of the substrates, peptide-MCA, was envisaged as fluorescent bands on dark background under UV transillumination. Partially purified midgut extract showed the presence of ten proteases. Fluorescent zymogram analysis indicated that there were five trypsin bands with molecular masses of $23,27,38$, 40, and $66 \mathrm{kDa}$ and two chymotrypsin bands with molecular masses of $\sim 29$ and $34 \mathrm{kDa}$ in the midgut extract of $H$. armigera (Fig. 2).

\subsection{Influence of $\mathrm{pH}$, temperature, and metal lons on the activity of serine proteases}

The proteases were highly active in the $\mathrm{pH}$ range of 8 to 12 , the optimum being 10.0 for both the enzymes. The optimum activity at $\mathrm{pH} 10.0$ for trypsin and chymotrypsin was found to be 4.01 and $4.95 \mathrm{U}$, respectively (Fig. 3A). The pH stability 

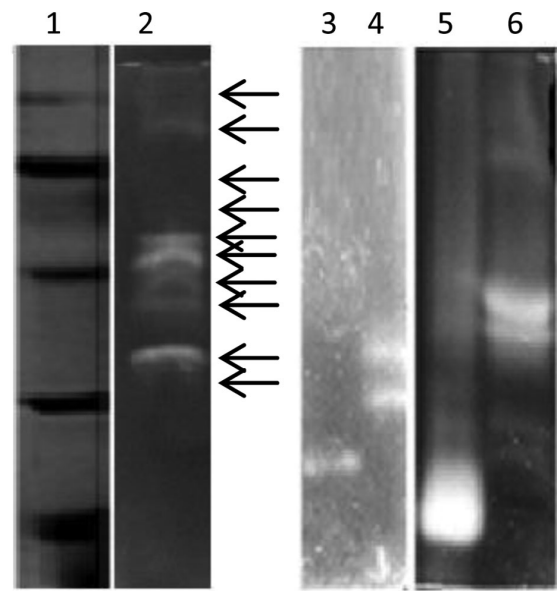

FIGURE 2 SDS-PAGE for detection of midgut serine proteases from H. armigera. Lane 1-molecular weight markers; lane 2-partially purified midgut extract, gel was stained with Coomassie Brilliant Blue after casein treatment; lane 3-bovine chymotrypsin (30 $\mu \mathrm{g})$; lane 4-midgut extract (50 $\mu \mathrm{g})$; lane 5-bovine trypsin (30 $\mu \mathrm{g})$; lane 6-midgut extract $(50 \mu \mathrm{g})$. Lanes 3 to 6 were stained for the detection of trypsin and chymotrypsin using specific fluorescent substrate as mentioned in the text

profile of the proteases indicated that these enzymes were stable in the $\mathrm{pH}$ range of 9.0 to 12.0 after $72 \mathrm{~h}$ of incubation, indicating the alkaline nature of the enzymes (Fig. 3B).

The enzymes were active at temperatures ranging from 40 to $80^{\circ} \mathrm{C}$, with optimum activity at 50 and $60^{\circ} \mathrm{C}$ for trypsin $\left(6.72 \mathrm{U}\right.$ ) and chymotrypsin $(5.68 \mathrm{U})$, respectively. The enzymatic activity was significantly reduced beyond $80^{\circ} \mathrm{C}$ (Fig. 3C). These enzymes remained active at 50 to $70^{\circ} \mathrm{C}$ even after $5 \mathrm{~h}$ of incubation. Incubation of trypsin and chymotrypsin at $80^{\circ} \mathrm{C}$ for $1 \mathrm{~h}$ reduced the enzymatic activity to 95 and $82 \%$ relative to the control, respectively (Fig. 3D).

Activity of trypsin was unaffected even at $3 \mathrm{M}$ concentration of $\mathrm{NaCl}$, but lost $60 \%$ of its activity at $5 \mathrm{M}$ concentration, whereas chymotrypsin was unaffected even at $5 \mathrm{M}$ of $\mathrm{NaCl}$ (Table 3). Both the proteases retained their activities in the presence of $\mathrm{K}^{+}, \mathrm{Ca}^{2+}, \mathrm{Zn}^{2+}, \mathrm{Cu}^{2+}, \mathrm{Mn}^{2+}, \mathrm{As}^{3+}, \mathrm{Mo}^{2+}, \mathrm{Hg}^{2+}$, and $\mathrm{Fe}^{2+}$. There was a difference in trypsin activity in presence of $\mathrm{Mg}^{2+}$ and $\mathrm{Fe}^{3+}$ but the increase in activity was nonsignificant. Trypsin activity was significantly affected in presence of $\mathrm{Pb}^{2+}$ and retained only $58 \%$ of residual activity, but the effect was nonsignificant on chymotrypsin activity.

\subsection{Influence of synthetic inhibitors on serine proteases}

Activities of trypsin and chymotrypsin were completely inhibited by the PMSF, aprotonin, leupeptin, pefabloc, and antipain. TLCK inhibited about $94 \%$ of trypsin activity, while TPCK and chymostatin inhibited about $90 \%$ of chymotrypsin activity. EDTA, EGTA, E64, pepstatin, idoacetamide, and bestatin did not affect the activities of trypsin and chymotrypsin (Table 4).

\subsection{Effect of surfactants and oxidizing and reducing agents on serine proteases}

Effect of anionic surfactant (SDS), nonionic surfactants (Tween-20, Tween-80, and Triton X-100), and oxidizing $\left(\mathrm{H}_{2} \mathrm{O}_{2}\right.$, and bleach) and reducing ( $\beta$-mercaptoethanol, DTE, DTT, urea) agents on the activities of trypsin and chymotrypsin is summarized in Table 5 . In the presence of $1 \mathrm{mM}$ of SDS, trypsin and chymotrypsin retained 66.5 and $94.5 \%$ of activities as compared to the control, whereas other surfactants did not affect the enzyme activities. In presence of $5 \% \mathrm{H}_{2} \mathrm{O}_{2}$ and bleach, about 15-25\% of the enzyme activities were inhibited, which was statistically nonsignificant. In presence of $1 \mathrm{mM}$ of $\beta$-mercaptoethanol, about 20 and $30 \%$ of trypsin and chymotrypsin activities were inhibited, respectively. Nearly $10-25 \%$ of the enzyme activities were inhibited in presence of DTE and DTT at $1 \mathrm{mM}$, but urea $(1 \mathrm{mM})$ did not affect the enzyme activities. 
a

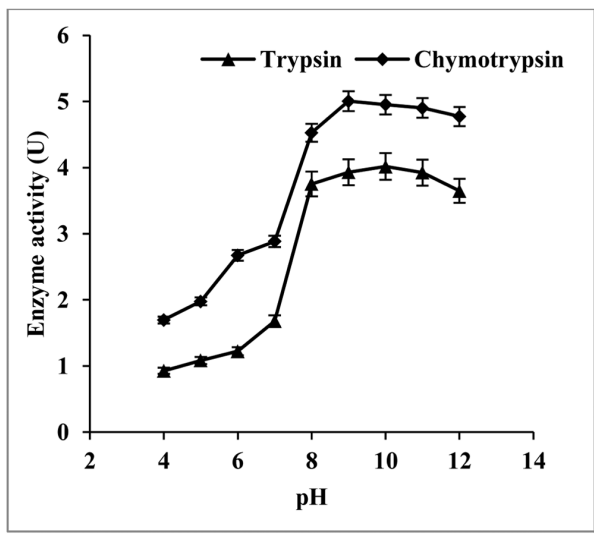

c

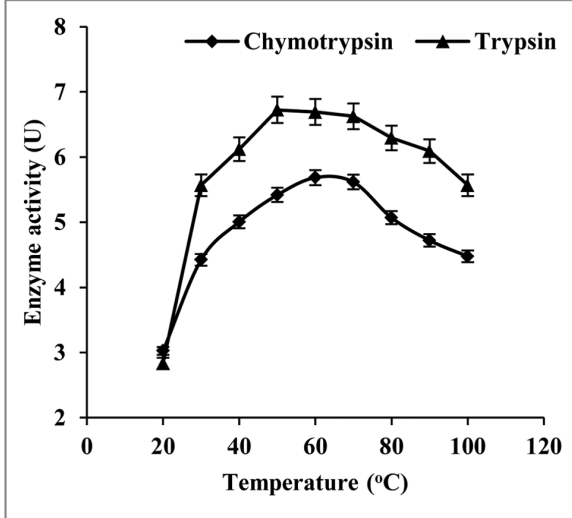

b

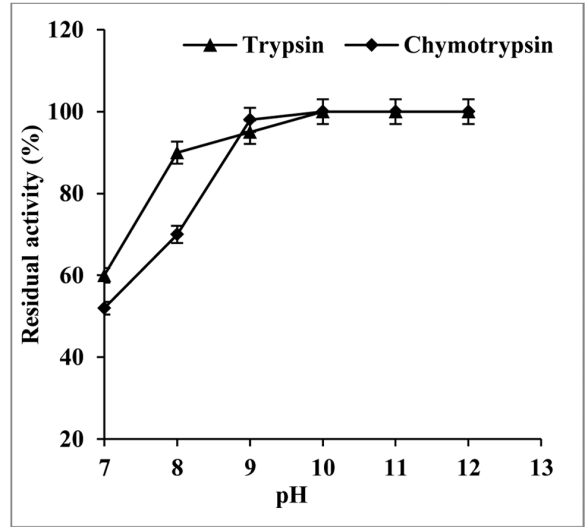

d

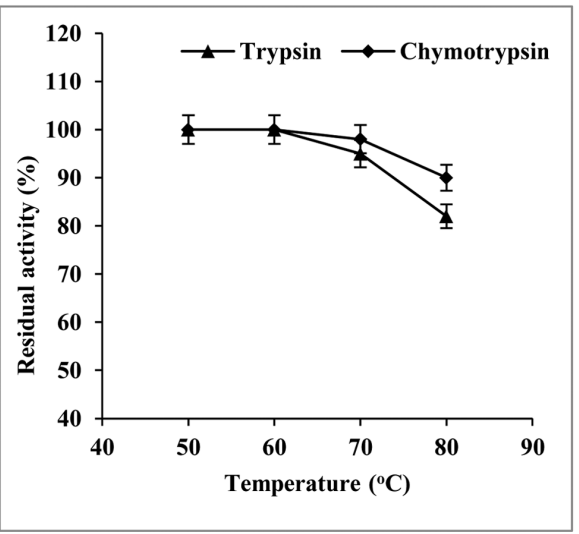

FIGURE 3 Influence of $\mathrm{pH}$ and temperature on the activity and stability of trypsin and chymotrypsin isolated from $\mathrm{H}$. armigera. Effect of $\mathrm{pH}$ on the activities of trypsin and chymotrypsin (a) and their stability to alkaline $\mathrm{pH}$ (b) was evaluated spectrophotometrically by incubating the purified enzymes in various buffers as stated in the text. Effect of temperature on the activities of trypsin and chymotrypsin (c) and their stability at extreme temperatures (d) was evaluated by incubating the enzymes in $0.1 \mathrm{Mglycine}-\mathrm{NaOH}$ buffer, $\mathrm{pH} 10.0$, at different temperatures as described in methodology. The data represent the mean of three replications (mean $\pm \mathrm{SD}$ )

\subsection{Stability of the serine proteases in the presence of organic solvents}

Activities of trypsin and chymotrypsin increased from 5 to $15 \%$ in presence of $5 \%$ organic solvents, but the effects were nonsignificant (Table 6).

\subsection{Effect of commercial detergents}

Trypsin and chymotrypsin exhibited $80 \%$ of the activities in presence of Ariel, Tide, and Surf detergents as compared to the control, but the activities were unaffected in the presence of Rin, Vanish, and Wheel (Table 7).

\section{4 | DISCUSSION}

Serine proteases in insects are comparable to those from mammals. Serine proteases are involved in the protein digestion and constitute nearly $95 \%$ of the total proteinase activities in a wide variety of insects (Chougule et al., 2008). Proteolytic enzymes play vital roles in development, growth, and reproduction processes in insects' life cycle (Terra 
TAB LE 3 Effect of metal ions on the activities of trypsin and chymotrypsinisolated from the midgut of $H$. armigera

\begin{tabular}{lcc|}
\hline Metal lon (1 mM) & Trypsin Activity (\%) & Chymotrypsin Activity (\%) \\
\hline Control & 100 & 100 \\
\hline $\mathrm{NaCl}(1 \mathrm{M})$ & $105.12 \pm 2.34$ & $100.05 \pm 2.45$ \\
\hline $\mathrm{NaCl}(3 \mathrm{M})$ & $85.23 \pm 2.54$ & $101.12 \pm 2.67$ \\
\hline $\mathrm{NaCl}(5 \mathrm{M})$ & $42.00 \pm 1.44^{\mathrm{b}}$ & $100.04 \pm 2.34$ \\
\hline $\mathrm{MgCl}_{2}$ & $127.45 \pm 2.45$ & $109.20 \pm 3.45$ \\
\hline $\mathrm{KCl}^{\mathrm{b}}$ & $102.12 \pm 2.66$ & $99.45 \pm 2.56$ \\
\hline $\mathrm{CuSO}_{4}$ & $102.05 \pm 2.33$ & $82.45 \pm 2.67$ \\
\hline $\mathrm{ZnCl}_{2}$ & $104.24 \pm 4.23$ & $96.78 \pm 2.66$ \\
\hline $\mathrm{CaCl}_{2}$ & $87.35 \pm 5.55$ & $106.34 \pm 2.56$ \\
\hline $\mathrm{FeSO}_{4}$ & $84.45 \pm 6.43$ & $98.23 \pm 3.22$ \\
\hline $\mathrm{FeCl}_{3}$ & $120.00 \pm 4.34$ & $109.45 \pm 3.33$ \\
\hline $\mathrm{MnCl}_{2}$ & $83.00 \pm 5.44$ & $93.54 \pm 2.33$ \\
\hline Sodium arsenite & $89.00 \pm 4.34$ & $100.04 \pm 0.44$ \\
\hline Lead acetate & $58.00 \pm 3.44^{\mathrm{b}}$ & $82.49 \pm 2.33$ \\
\hline $\mathrm{Molybdenum}^{\mathrm{b}}$ & $81.00 \pm 4.44$ & $82.56 \pm 2.45$ \\
\hline $\mathrm{Mercuric}$ & $83.00 \pm 3.43$ & $90.56 \pm 3.54$ \\
\hline
\end{tabular}

aValues in the table represents mean of three replications (mean $\pm \mathrm{SE}$ ).

${ }^{b}$ Significantly different from control at $P<0.05$.

\& Ferreira, 1994). Serine proteases are characterized by a catalytic serine residue which in fact is a catalytic triad (serine, histidine, and aspartic acid) (Hedstrom, 2002). Trypsin (EC 3.4.21.4) and chymotrypsin (EC 3.4.21.1) are the major proteolytic enzymes belonging to this family (Reeck et al., 1999; Terra \& Ferreira, 1994). The present study describes the characterization of serine proteases from the midgut of $H$. armigera. The proteases were purified by employing column chromatographic techniques such as hydroxyl apatite, CM sephadex, and DEAE sephadex. $K_{m}$ for the substrates BApNA and SAAPFpNA was found to be 1.25 and $0.085 \mathrm{mM}$, with a low $K_{\mathrm{m}}$ for the latter with chymotrypsin. Zymogram analysis performed for the detection of proteases in the partially purified midgut extract indicated the presence of 10 proteases and the results were in agreement with that of earlier studies (Parde et al., 2012). Fluorescence zymogram analysis performed using specific fluorescent substrates for trypsin and chymotrypsin indicated that among the ten proteases, there were five trypsin bands with molecular masses of $\sim 23,27,38$, 40, and 66 $\mathrm{kDa}$ and two chymotrypsin bands with the molecular masses of $\sim 29$ and $34 \mathrm{kDa}$ in the midgut extract of $\mathrm{H}$. armigera. Trypsin and chymotrypsin are the most common enzymes characterized in insect digestive system (Lopes \& Terra, 2003; Mazumdar-Leighton \& Broadway, 2001). About four to seven active proteolytic enzymes have been detected with casein zymogram in insects: T. molitor (Zwilling, 1968), Astacus fluviatilis (Pfleiderer et al., 1967), Carcinus maenas (Linke et al., 1969), Apis mellifica L. (Giebel et al., 1971) and Rhyzopertha dominica (F.) (Zhu \& Baker, 1999).

The proteases from $\mathrm{H}$. armigera exhibited a parabolic dependency on $\mathrm{pH}$ of the medium, and were highly active in the $\mathrm{pH}$ range of 8 to 12, the optimum being 10.0 for both the enzymes. Activities of both the enzymes were reduced under acidic $\mathrm{pH}(<6.0)$. Alkaline $\mathrm{pH}$ optima observed for the proteases was due to the intrinsic alkaline $\mathrm{pH}$ conditions of the insect midgut. Midgut proteases reported from Spilosoma obliqua Walker (pH 11.0) (Anwar \& Saleemuddin, 2002), cockroach (pH 8.0) (Lopes \& Terra, 2003; Sanatan et al., 2013), H. armigera (pH 10.0) (Parde et al., 2012), and T. molitor Linnaeus (pH 8.5) (Tsybina et al., 2005) were active in the $\mathrm{pH}$ range of 7.0 to 12.0. The alkaline $\mathrm{pH}$ of insects' midgut has been attributed to digestion and absorption of the nutrients from plants, an adaptation for extracting hemicelluloses from plant cell walls (Tsybina et al., 2005). Trypsin and chymotrypsin from H. armigera were resistant to thermal inactivation at high temperatures up to $80^{\circ} \mathrm{C}$. These enzymes were active at temperatures ranging from 40 to $80^{\circ} \mathrm{C}$, with an optimum activity at $50^{\circ} \mathrm{C}$. The alkaline proteases from other insects have also been found to be thermostable. Optimum 
TAB LE 4 Effect of synthetic protease inhibitors on the activities of trypsin and chymotrypsin in $H$. armigera

\begin{tabular}{lcc} 
& & Relative Activity (\%) $^{\mathrm{a}}$ \\
\cline { 2 - 3 } Treatment & Trypsin & Chymotrypsin \\
\hline Control & 100.00 & 100.00 \\
\hline PMSF & $3.20 \pm 2.55^{\mathrm{b}}$ & $2.88 \pm 2.45^{\mathrm{b}}$ \\
\hline EDT & $95.00 \pm 3.45$ & $96.40 \pm 3.56$ \\
\hline aEGT & $100.23 \pm 2.56$ & $98.00 \pm 4.23$ \\
\hline aTPCK & $96.12 \pm 2.45$ & $11.18 \pm 2.56^{\mathrm{b}}$ \\
\hline TLCK & $6.80 \pm 4.56^{\mathrm{b}}$ & $102.13 \pm 3.22$ \\
\hline Aprotonin & $19.49 \pm 4.56^{\mathrm{b}}$ & $15.00 \pm 4.67^{\mathrm{b}}$ \\
\hline Leupeptin & $8.19 \pm 3.34^{\mathrm{b}}$ & $13.00 \pm 3.21^{\mathrm{b}}$ \\
\hline E64 & $94.08 \pm 2.45$ & $98.99 \pm 3.56$ \\
\hline Pepstatin & $91.84 \pm 2.67$ & $100.00 \pm 0.04$ \\
\hline lodoacetamide & $87.20 \pm 2.87$ & $99.00 \pm 1.11$ \\
\hline Pefabloc & $12.00 \pm 2.98^{\mathrm{b}}$ & $14.00 \pm 1.45^{\mathrm{b}}$ \\
\hline Bestatin & $92.35 \pm 3.56$ & $101.26 \pm 1.56$ \\
\hline Antipain & $11.08 \pm 6.56^{\mathrm{b}}$ & $28.05 \pm 2.32^{\mathrm{b}}$ \\
\hline Chymostatin & $92.00 \pm 3.32$ & $12.75 \pm 1.45^{\mathrm{b}}$ \\
\hline
\end{tabular}

${ }^{a}$ Values in the table represents mean of three replications (mean $\pm \mathrm{SE}$ ).

${ }^{b}$ Significantly different from control at $P<0.01$.

TAB LE 5 Effect of surfactants and oxidizing and reducing agents on the activities of trypsin and chymotrypsin isolated from the midgut of $\mathrm{H}$. armigera

\begin{tabular}{|c|c|c|}
\hline \multirow[b]{2}{*}{ Treatment } & \multicolumn{2}{|c|}{ Relative Activity (\%) } \\
\hline & Trypsin & Chymotrypsin \\
\hline Control & 100.00 & 100.00 \\
\hline \multicolumn{3}{|l|}{ Surfactants } \\
\hline SDS & $66.50 \pm 0.25^{b}$ & $94.50 \pm 2.77$ \\
\hline CHAPS & $119.70 \pm 1.23$ & $101.22 \pm 3.21$ \\
\hline Triton X-100 & $115.11 \pm 2.22$ & $84.52 \pm 3.65$ \\
\hline Tween 20 & $102.35 \pm 2.67$ & $95.23 \pm 2.88$ \\
\hline Tween 80 & $110.14 \pm 1.87$ & $90.74 \pm 1.45$ \\
\hline \multicolumn{3}{|l|}{ Oxidizing agents } \\
\hline $\mathrm{H}_{2} \mathrm{O}_{2}$ & $87.98 \pm 2.65$ & $86.44 \pm 1.76$ \\
\hline Bleach & $75.12 \pm 2.67$ & $82.14 \pm 0.87$ \\
\hline \multicolumn{3}{|l|}{ Reducing agents } \\
\hline$\beta$-mercaptoethanol & $81.73 \pm 3.76$ & $68.26 \pm 2.44^{b}$ \\
\hline DTE & $85.69 \pm 4.76$ & $92.73 \pm 1.67$ \\
\hline DTT & $89.77 \pm 1.67$ & $91.72 \pm 2.45$ \\
\hline Urea & $102.38 \pm 2.56$ & $101.54 \pm 1.45$ \\
\hline
\end{tabular}

aValues in the table represents mean of three replications (mean $\pm \mathrm{SE}$ ).

bSignificantly different from control at $P<0.05$. 
TAB LE 6 Effect of solvents on the activities of trypsin and chymotrypsin isolated from the midgut of $H$. armigera

\begin{tabular}{|lcr|} 
& & \\
& & Relative Activity (\%) $^{\mathrm{a}}$ \\
\cline { 2 - 3 } Treatment & Trypsin & Chymotrypsin \\
\hline Control & 100.00 & 100.00 \\
\hline Methanol & $114.50 \pm 4.45$ & $114.39 \pm 3.36$ \\
\hline Ethanol & $118.80 \pm 3.32$ & $105.77 \pm 3.36$ \\
\hline Propanol & $125.55 \pm 2.25$ & $97.33 \pm 2.25$ \\
\hline Butanol & $127.00 \pm 5.42$ & $105.30 \pm 1.25$ \\
\hline Acetone & $112.63 \pm 2.65$ & $112.55 \pm 1.25$ \\
\hline Hexane & $115.17 \pm 1.25$ & $111.62 \pm 1.25$ \\
\hline DMSO & $93.41 \pm 0.06$ & $118.98 \pm 2.69$ \\
\hline DMF & $118.87 \pm 2.23$ & $110.17 \pm 1.25$ \\
\hline Benzene & $125.56 \pm 3.36$ & $112.59 \pm 0.36$ \\
\hline Toluene & $86.75 \pm 1.25$ & $108.69 \pm 1.25$ \\
\hline Diethylether & $117.68 \pm 2.69$ & $90.00 \pm 5.58$ \\
\hline Chloroform & $116.72 \pm 1.15$ & $106.06 \pm 6.65$ \\
\hline
\end{tabular}

${ }^{a}$ Values in the table represents mean of three replications (mean $\pm \mathrm{SE}$ ).

TAB LE 7 Effect of commercial detergents on the activities of trypsin and chymotrypsin isolated from the midgut of H. armigera

\begin{tabular}{lcr} 
& \multicolumn{2}{c}{ Relative Activity (\%) $^{\text {a }}$} \\
\cline { 2 - 3 } Treatment & Trypsin & Chymotrypsin \\
\hline Control & 100.00 & 100.00 \\
\hline Ariel & $78.00 \pm 1.23$ & $75.00 \pm 2.25$ \\
\hline Tide & $80.00 \pm 1.56$ & $78.00 \pm 1.15$ \\
\hline Surf & $82.00 \pm 1.58$ & $80.00 \pm 2.36$ \\
\hline Rin & $96.06 \pm 1.65$ & $97.17 \pm 2.22$ \\
\hline Vanish & $92.00 \pm 2.63$ & $92.56 \pm 2.23$ \\
\hline Wheel & $95.00 \pm 2.20$ & $98.00 \pm 1.45$ \\
\hline
\end{tabular}

a Values in the table represents mean of three replications (mean $\pm \mathrm{SE}$ ).

temperature for the proteolytic activity of alkaline serine proteases in S. obliqua, O. coerulescens, and P. americana was reported to be 50,55 , and $60^{\circ} \mathrm{C}$, respectively (Anwar \& Saleemuddin, 2002; Sanatan et al., 2013; Sharifi et al., 2012). Activities of trypsin and chymotrypsin were unaffected at higher concentration of $\mathrm{NaCl}(3 \mathrm{M})$. Serine alkaline protease in P. americana was unaffected in presence of $\mathrm{NaCl}$ (Sanatan et al., 2013), whereas in G. pyloalis larvae, the proteolytic activity was reduced by about 38\% in presence of $5 \mathrm{mM} \mathrm{NaCl}$ (Mahdavi, et al., 2013). Protease with salt-tolerant nature is the exclusive characteristic of halotolerant microbes. Proteases with proteolytic activities in a wide range of $\mathrm{pH}$, and stability to salt (approx. 3 M) and solvents have been reported from microbial sources (Kumar \& Takagi, 1999; Santos et al., 2013). Proteases with stability at high temperature and salt concentrations, and alkaline pH optima are desirable for applications in detergents and tanning (Joo et al., 2003).

Activities of both trypsin and chymotrypsin were unaffected in presence of metal ions except $\mathrm{Pb}^{2+}$. $\mathrm{Protease}$ activity was affected due to metals ions in Conogethes punctiferalis (Guenee) larvae (Josephrajkumar et al., 2006). $\mathrm{Na}^{+}, \mathrm{Ca}^{2+}, \mathrm{Co}^{2+}$, and $\mathrm{Mn}^{2+}$ reduced the protease activity in lesser mulberry pyralid, G. pyloalis (Mahdavi, et al., 2013). Proteases having extreme stability toward various metal ions are suitable in tanning processing and sewage treatment (Li et al., 2010). TLCK, an irreversible trypsin inhibitor, decreased hydrolysis of L-BApNA but did not 
affect chymotrypsin in H. armigera. TLCK inhibited trypsin-like enzyme activity in R. dominica and Anticarsia gemmatalis (Hübner) (Xavier et al., 2005; Zhu \& Baker, 1999). TPCK and chymostatin, being potent inhibitors of chymotrypsin, inhibited the chymotrypsin-like enzyme activity in the present study. In contrast, TPCK and TLCK did not affect the chymotrypsin-like enzyme activity in T. molitor larvae and Apis mellifera (Elpidina et al., 2005; Matsuoka et al., 2015). Serine protease inhibitors, PMSF, aprotonin, leupeptin, pefabloc, and antipain completely inhibited the activities of both the enzymes. Also, the proteases were insensitive to EDTA and EGTA, suggesting that the enzymes did not require metal ions for their catalytic activity, in contrary to the mammalian proteases. PMSF, aprotinin, and leupeptin inhibited trypsin-like activity in lesser grain borer, R. dominica (Zhu \& Baker, 1999). PMSF completely inhibited the chymotrypsin-like enzyme, but EDTA did not affect the enzyme activity in T. molitor larvae (Elpidina, et al., 2005). Trypsin-like activity was inhibited by PMSF, EDTA, benzamidine, and aprotonin in velvetbean caterpillar, A. gemmatalis (Xavier et al., 2005). A nonsignificant reduction in the enzyme activities of both the enzymes was observed in presence of oxidizing agents. Among the tested surfactants, SDS and $\beta$-mercaptoethanol slightly affected the trypsin and chymotrypsin activity, respectively. Chymotrypsin-like enzyme activity was substantially inhibited by 2-mercaptoethanol in T. molitor larvae (Elpidina, et al., 2005). Surfactants and oxidizing agents did not affect the serine alkaline protease in P. americana at $1 \%$ (Sanatan et al., 2013). Thus, there was a differential response of alkaline serine proteases to the metal ions, synthetic protease inhibitors, and surfactants from insects.

There is great industrial demand for organic solvent-stable proteases in making of pharmaceutical products and peptide synthesis in molecular biology (Gupta et al., 1999; Motyan et al., 2013). Usually in aqueous environments, enzymes possess the conformational mobility to perform the catalytic activity optimally, which is lost during organic solvents treatment in industrial processing. Purified trypsin and chymotrypsin from the midgut of $\mathrm{H}$. armigera were resistant to tested solvents and commercial detergent. These properties of serine proteases from $\mathrm{H}$. armigera can be exploited in industrial application. Industrially important proteases with tolerance to alkalinity and extreme temperatures have been known to be reported from microbial source. Thus, it can be expected that the serine alkaline proteases purified from the midgut of $\mathrm{H}$. armigera could belong to the symbiotic bacteria residing in the midgut. However, Visweshwar et al. (2015) has successfully demonstrated that zymogram analysis of midgut proteases in H. armigera when administered on antibiotic cocktail for exclusion of midgut bacteria exhibited inhibition of only one protease among the nine proteases reported in control larvae suggests that most of the observed proteases in zymogram belong to insect larvae. Therefore, insects could be a better option over microbial source in producing multiple forms of proteases in their midgut for application in industrial purposes.

Serine alkaline proteases are a commercially important group of enzymes for biotechnological applications, including clinical, pharmaceutical, and analytical chemistry (Joo \& Chang, 2005; Joo et al., 2004; Samal et al., 1990). Alkaline proteases are also an important constituent in detergent formulations to remove a variety of stains such as blood, tea, curd, and so on, from clothes at elevated $\mathrm{pH}$ and temperatures. Nonenzymatic removal of proteins may lead to a permanent stain on the clothes due to oxidation caused by bleaching and drying. Proteases breakdown the proteins into soluble polypeptides or free amino acids and effectively remove the stains along with the surfactant from fibers. Enzymes to be used in detergents must be effective at lower concentrations and compatible with various detergent components and remain active in presence of a wide range of chemicals and temperatures (Kumar \& Takagi, 1999). The larvae of Sarconesiopsis magellanica (Le Guillou) and Lucilia sericata (Meigen) used in healing necrotic wounds release proteolytic enzymes in their excretion and secretion that help in wound healing (Pinilla et al., 2013).

Pancreatic proteases from animal origin such as trypsin, chymotrypsin, renin, and pepsin, though are readily available, the availability of enzymes depends on the livestock for slaughter, which is also governed by government policies (Rao et al., 1998). Therefore, alkaline proteases from H. armigera with high stability under higher temperatures and salt concentrations can play an important role in industrial processes. Another advantage of $H$. armigera is to easily produce copious numbers of the insect larvae under laboratory conditions using an inexpensive artificial diet. Insects can be more advantageous over microbial proteases due to their short life cycles, voracious feeding behavior, and production of multiple forms of proteases in the midguts for digestion. Insect proteases with rapid catalytic ability, wide range of physical and chemical characteristics, and stability under extreme environmental conditions and chemicals 
make insect proteases more suitable biocatalysts for various industrial applications. Protein engineering from insects will broaden the applications of proteases for various purposes. Characterization of proteolytic digestive enzymes of insect origin also offers opportunities for developing suitable and effective pest management strategies via serine protease inhibitors for deployment in transgenics for sustainable crop production.

\section{5 | CONCLUSION}

In the present study, alkaline serine proteases from $\mathrm{H}$. armigera were characterized for their potential applications to industrial usage. Zymographic analyses revealed the presence of multiple isozymes for trypsin and chymotrypsin, and the purified proteases were thermophilic, alkalophilic, and salt tolerant, and exhibited high stability and compatibility with solvents and detergents and oxidizing and bleaching agents. The results suggested that proteases from H. armigera have unique properties, which can be exploited in various industrial applications.

\section{ACKNOWLEDGMENTS}

We thank the staff of Entomology Unit, International Crops Research Institute for the Semi-Arid Tropics (ICRISAT), for providing support for insect rearing. This study was funded by Department of Science and Technology - Scientific and Engineering Research Board (DST-SERB), New Delhi, India.

\section{CONFLICT OF INTEREST}

All the authors declare no conflict of interest, financial or otherwise, that might possibly bias this work.

\section{LITERATURE CITED}

Abidi, F., Limam, F., \& Nejib, M. M. (2008). Production of alkaline proteases by Botrytis cinerea using economic raw materials: Assay as biodetergent. Process Biochemistry, 43, 1202-1208.

Anwar, A., \& Saleemuddin, M. (2002). Purification and characterization of a digestive alkaline protease from the larvae of Spilosoma obliqua. Archives of Insect Biochemistry and Physiology, 51, 1-12.

Applebaum, S. W., Birk, Y., Harpaz, I., \& Bondi, A. (1964). Comparative studies on proteolytic enzymes of Tenebrio molitor L. Comparative Biochemistry and Physiology, 11, 85-103.

Chitti Babu, G., Sharma, H. C., Madhumati, T., Raghavaiah, G., Murthy, K. V. M. K., \& Rao, V. S. (2014). A semi-synthetic chickpea flour based diet for long-term maintenance of laboratory culture of Helicoverpa armigera. Indian Journal of Entomology, 76 , 336-340.

Chougule, N. P., Doyle, E., Fitches, E., \& Gatehouse, J. A. (2008). Biochemical characterization of midgut digestive proteases from Mamestra brassicae (cabbage moth; Lepidoptera: Noctuidae) and effect of soybean Kunitz inhibitor (SKTI) in feeding assays. Journal of Insect Physiology, 54, 563-572.

Christeller, J. T., Laing, W. A., Markwick, N. P., \& Burgess, E. P. J. (1992). Midgut protease activities in 12 phytophagous lepidopteran larvae: Dietary and protease inhibitor interactions. Insect Biochemistry and Molecular Biology, 22, 735-746.

Elpidina, E. N., Tsybina, T. A., Dunaevsky, Y. E., Belozersky, M. A., Zhuzhikov, D. P., \& Oppert, B. (2005). A chymotrypsin-like proteinase from the midgut of Tenebrio molitor larvae. Biochimie, 87, 771-779.

Gatehouse, L. N., Shannon, A. L., Burgess, E. P. J., \& Christeller, J. T. (1997). Characterization of major midgut proteinase cDNAs from Helicoverpa armigera larvae and changes in gene expression in response to four proteinase inhibitors in the diet. Insect Biochemistry and Molecular Biology, 27, 929-944.

Giebel, W., Zwilling, R., \& Pfleiderer, G. (1971). The evolution of endopeptidases - Xii. The proteolytic enzymes of the honeybee (Apis mellifica L.). Comparative Biochemistry and Physiology, 38B, 197-210.

Gupta, R., Beg, Q., \& Lorenz, P. (2002). Bacterial alkaline proteases: Molecular approaches and industrial applications. Applied Microbiology and Biotechnology, 59, 15-32.

Gupta, R., Gupta, K., \& Khan, S. (1999). Bleach-stable alkaline protease from Bacillus sp. Biotechnology Letters, 21, $135-138$.

Hedstrom, L. (2002). Serine protease mechanism and specificity. Chemical Reviews, 102(12), 4501-4524. 
Joo, H. S., \& Chang, C. S. (2005). Oxidant and SDS stable alkaline protease from a halotolerant Bacillus clausii I-52: Enhanced production and simple purification. Journal of Applied Microbiology, 98, 491-497.

Joo, H. S., Kumar, C. G., Park, G. C., Paik, S. R., \& Chang, C. S. (2003). Oxidant and SDS-stable alkaline protease from Bacillus clausii I-52: Production and some properties. Journal of Applied Microbiology, 95, 267-272.

Joo, H. S., Kumar, C. G., Park, S. R., \& Chang, C. S. (2004). Bleach resistance alkaline protease produced by a Bacillus species isolated from the Korean Polychaete Perriserrula leucophryna. Process Biochemistry, 39, 1441-1447.

Josephrajkumar, A., Chakrabarty, R., \& Thomas, G. (2006). Midgut proteases of the cardamom shoot and capsule borer Conogethes punctiferalis (Lepidoptera: Pyralidae) and their interaction with aprotinin. Bulletin of Entomological Research, 96, 9198.

Kumar, C. G., \& Takagi, H. (1999). Microbial alkaline proteases: From a bioindustrial viewpoint. Biotechnological Advances, 17, 561-594.

Laemmli, U. K. (1970). Cleavage of structural proteins during assembly of the head of bacteriophage T4. Nature, 227, $680-685$.

Li, Z. Y., Youravong, W., \& H-Kittikun, A. (2010). Protein hydrolysis by protease isolated from tuna spleen by membrane filtration: A comparative study with commercial proteases. LWT - Food Science and Technology, 43(1), 166-172.

Linke, R., Zwilling, R., Herbold, D., \& Pfleiderer, G. (1969). Immunologische untersuchungen des trypsins und der niedermolekularen protease aus drei decapoden crustaceen.Zeitschrift fur Physiologische Chemie, 350, 877-885.

Lopes, A. R., \& Terra, W. R. (2003). Purification, properties and substrate specificity of a digestive trypsin from Periplaneta americana (Dictyoptera). Insect Biochemistry and Molecular Biology, 33, 407-415.

Lowry, O. H., Rosenbrough, N. J., Farr, A. L., \& Randal, A. J. (1951). Protein measurements with the folin phenol reagent. Journal of Biological Chemistry, 193, 265-275.

Mahdavi, A., Ghadamyari, M., Sajedi, R. H., Sharifi, M., \& Kouchaki, B. (2013). Identification and partial characterization of midgut proteases in the lesser mulberry pyralid, Glyphodes pyloalis. Journal of Insect Science, 13, 81.

Matsuoka, T., Takasaki, A., Mishima, T., Kawashima, T., Kanamaru, Y., Nakamura, T., \& Yabe, T. (2015). Expression and characterization of honeybee, Apis mellifera, larva chymotrypsin-like protease. Apidologie, 46, 167-176.

Mazumdar-Leighton, S., \& Broadway, R. M. (2001). Identification of six chymotrypsin cDNAs from larval midguts of Helicoverpa zea and Agrotis ipsilon feeding on the soybean (Kunitz) trypsin inhibitor. Insect Biochemistry and Molecular Biology, 31, 633644.

Motyan, J. A., Tóth, F., \& Tőzsér, J. (2013). Research applications of proteolytic enzymes in molecular biology. Biomolecules, 3 , 923-942.

Nunes, A. S., \& Martins, M. L. (2001). Isolation, properties and kinetics of growth of a thermophilic Bacillus. Brazilian Journal of Microbiology, 32, 271-275.

Parde, V. D., Sharma, H. C., \& Kachole, M. S. (2012). Inhibition of Helicoverpa armigera gut pro-proteinase activation in response to synthetic protease inhibitors. Entomologia Experimentalis et Applicata, 142, 104-113.

Patankar, A. G., Giri, A. P., Harsulkar, A. M., Sainani, M. N., Deshpande, V. V., Ranjekar, P. K., \& Gupta, V. S. (2001). Complexity in specificities and expression of Helicoverpa armigera gut proteinases explains polyphagous nature of the insect pest. Insect Biochemistry and Molecular Biology, 31, 453-464.

Pfleiderer, G., Zwilling, R., \& Sonneborn, H.-H. (1967). Eine Protease vom Molekulargewicht 11,000 und eine trypsinaihnliche Fraktion aus Astacus fluviatilis Fabr. Zeitschrift fur Physiologische Chemie, 348, 1319-1331.

Pinilla, Y. T., Moreno-Pérez, D. A., Patarroyo, M. A., \& Bello, F. J. (2013). Proteolytic activity regarding Sarconesiopsis magellanica (Diptera: Calliphoridae) larval excretions and secretions. Acta Tropica, 128, 686-691.

Purushottam, R. L., \& Vandana, K. H. (2013). Effect Bacillus thuringiensis (Bt) Cry1Ac toxin and protease inhibitor on growth and development of Helicoverpa armigera (Hubner). Pesticide Biochemistry and Physiology, 105, 77-83.

Rao, M. B., Tanksale, A. M., Ghatge, M. S., \& Deshpande, V. V. (1998). Molecular and biotechnological aspects of microbial proteases. Microbiology and Molecular Biology Reviews, 62(3), 597-635.

Reeck, G., Oppert, B., Denton, M., Kanost, M., Baker, J., \& Kramer, K. (1999). Insect proteinases. In: V. Turk (Eds.), Proteases: New perspectives (pp. 125-148). Basel: Birkhauser Verlag.

Samal, B. B., Karan, B., \& Stabinsk, Y. (1990). Stability of two novel serine proteinases in commercial laundry detergent formulations. Biotechnology and Bioengineering, 35, 650-652.

Sanatan, P. T., Lomate, P. R., Giri, A. P., \& Hivrale, V. K. (2013). Characterization of a chemostable serine alkaline protease from Periplaneta americana. BMC Biochemistry, 14, 32.

Santos, A. F., Valle, R. S., Pacheco, C. A., Alvarez, V. M., Seldin, L., \& Santos, A. L. S. (2013). Extracellular proteases of Halobacillus blutaparonensis strain M9, a new moderately halophilic bacterium. Brazilian Journal of Microbiology, 44(4), $1299-1304$. 
Sharifi, M., Chitgar, M. G., Ghadamyari, M., \& Ajamhasani, M. (2012). Identification and characterization of midgut digestive proteases from the rosaceous branch borer, Osphranteria coerulescens Redtenbacher (Coleoptera: Cerambycidae). Romanian Journal of Biochemistry, 49(1), 33-47

Sharma, H. C. (2005). Heliothis/Helicoverpa management: Emerging trends and strategies for future research. New Delhi: Oxford and IBH Publishing.

Singh, J., Vohra, R. M., \& Sahoo, D. K. (1999). Alkaline protease from a new obligate alkalophilic isolate of Bacillus sphaericus. Biotechnology Letters, 21, 921-924.

Srinivasan, A., Giri, A. P., \& Gupta, V. S. (2006). Structural and functional diversities in lepidopteran serine proteases. Cellular and Molecular Biology Letters, 11, 132-154.

Tabatabaei, P. R., Hosseininaveh, V., Goldansaz, S. H., \& Talebi, K. H. (2011). Biochemical characterization of digestive proteases and carbohydrases of the carob moth, Ectomyelois ceratoniae (Zeller) (Lepidoptera: Pyralidae). Journal of Asia-Pacific Entomology, 14, 187-194.

Terra, W. R., \& Ferreira, C. (1994). Insect digestive enzymes: Properties, compartmentalization and function. Comparative Biochemistry and Physiology, 109B, 1-62.

Tsybina, T. A., Dunaevsky, Y. E., Belozersky, M. A., Zhuzhikov, D. P., Oppert, B., \& Elpidina, E. N. (2005). Digestive proteinases of yellow mealworm (Tenebrio molitor) larvae: Purification and characterization of a trypsin-like proteinase. Biochemistry (Moscow), 70, 300-305.

Visweshwar, R., Sharma, H. C., Akbar, S. M. D., \& Sreeramulu, K. (2015). Elimination of gut microbes with antibiotics confers resistance to Bacillus thuringiensis toxin proteins in Helicoverpa armigera (Hubner). Applied Biochemistry and Biotechnology, 177, 1621-1637.

Xavier, L. P., Oliveira, M. G. A., Guedes, R. N. C., Santos, A. V., \& De Simone, S. G. (2005). Trypsin-like activity of membrane-bound midgut proteases from Anticarsia gemmatalis (Lepidoptera: Noctuidae). European Journal of Entomology, 102, $147-153$.

Yasothornsrikul, S., \& Hook, V. Y. H. (2000). Detection of proteolytic activity by fluorescent zymogram in-gel assays. BioTechniques, 28, 1166-1173.

Zambare, V. P., Nilegaonkar, S. S., \& Kanekar, P. P. (2007). Production of an alkaline protease and its application in dehairing of buffalo hide. World Journal of Microbiology and Biotechnology, 23, 1569-1574.

Zhu, Y. C., \& Baker, J. E. (1999). Characterization of midgut trypsin-like enzymes and three trypsinogen cDNAs from the lesser grain borer, Rhyzopertha dominica (Coleoptera: Bostrichidae). Insect Biochemistry and Molecular Biology, 29, $1053-1063$.

Zwilling, R. (1968). Zur Evolution der Endopeptidasen - IV. $\alpha$ - and ß-Protease aus Tenebrio molitor. Zeitschrift fur Physiologische Chemie, 349, 326-332.

How to cite this article: Akbar SMD and Sharma HC. Alkaline serine proteases from Helicoverpa armigera: potential candidates for industrial applications. Arch Insect Biochem Physiol. 2017;94:e21367. doi: 10.1002/ arch.21367. 